\title{
RpfF-Dependent Regulon of Xylella fastidiosa
}

\author{
Nian Wang, Jian-Liang Li, and Steven E. Lindow
}

First and third authors: Department of Plant and Microbial Biology, University of California, Berkeley 94720; and second author: Sanford Burnham Medical Research Institute at Lake Nona 6400 Sanger Road Orlando, FL 32827.

Current address of N. Wang: Citrus Research and Education Center, Department of Microbiology and Cell Science, University of Florida, 700 Experiment Station Road, Lake Alfred 33850. Accepted for publication 30 July 2012.

\begin{abstract}
Wang, N., Li, J.-L., and Lindow, S. E. 2012. RpfF-dependent regulon of Xylella fastidiosa. Phytopathology 102:1045-1053.

Xylella fastidiosa regulates traits important to both virulence of grape as well as colonization of sharpshooter vectors via its production of a fatty acid signal molecule known as DSF whose production is dependent on $r p f F$. Although $X$. fastidiosa rpfF mutants exhibit increased virulence to plants, they are unable to be spread from plant to plant by insect vectors. To gain more insight into the traits that contribute to these processes, a whole-genome Agilent DNA microarray for this species was developed and used to determine the RpfF-dependent regulon by transcriptional profiling. In total, 446 protein coding genes whose expression

discovery rate $<0.05)$ were identified when cells were grown in PW liquid medium. Among them, 165 genes were downregulated in the $r p f F$ mutant compared with the wild-type strain whereas 281 genes were overexpressed. RpfF function was required for regulation of 11 regulatory and $\sigma$ factors, including $r p f E$, yybA, PD1177, $g \ln B, r p f G$, PD0954, PD0199, $\mathrm{PD} 2050$, colR, rpoH, and rpoD. In general, RpfF is required for regulation of genes involved in attachment and biofilm formation, enhancing expression of hemagglutinin genes $h x f A$ and $h x f B$, and suppressing most type IV pili and gum genes. A large number of other RpfF-dependent genes that might contribute to virulence or insect colonization were also identified such as those encoding hemolysin and colicin V, as well as genes with unknown functions.
\end{abstract} was significantly different between the wild type and an $r p f F$ mutant (false
Pierce's disease of grape, a chronic problem in the grape industry in California now promises to be a far more devastating disease due to the introduction of the glassy-winged sharpshooter (Homalodisca vitripennis), a more effective vector of the pathogen Xylella fastidiosa $(10,43)$. This disease has long limited production of grape in many other areas of North America where warm climatic conditions and the presence of sharpshooter vectors coincide (43). X. fastidiosa apparently causes disease by multiplying within and, thus, blocking xylem vessels $(33,35)$. The process of grape vessel and insect colonization by $X$. fastidiosa has many similarities to the process of microbial biofilm formation in other aquatic systems, where thick layers of cells can form on solid surfaces that are exposed to a flow of liquids. Cells in these structures are often embedded in an EPS matrix after initial attachment to the surface (52). Cells in biofilms are often more resistant to many stresses such as antimicrobial compounds, viruses, and predators. The EPS matrix can also facilitate growth of the cells by accumulating various types of nutrients in a way analogous to an ion-exchange column (56) as well as other extracellular products such as enzymes and signal molecules. Small molecules such as $\mathrm{N}$-acyl homoserine lactones (AHLs), peptides, and fatty acids play key roles as signals that coordinate biofilm formation in numerous species of bacteria $(6,55)$. The signals, which increase in concentration with population density, also often coordinate the expression of genes involved in exploitation of a host organism. The virulence of many pathogens is usually greatly reduced when the ability to produce signaling molecules is disrupted.

Corresponding author: S. E. Lindow; E-mail address: icelab@berkeley.edu

* The $\boldsymbol{e}$-Xtra logo stands for "electronic extra" and indicates that the online version contains two supplementary figures and one supplementary table.

http://dx.doi.org/10.1094/PHYTO-07-12-0146-R

(c) 2012 The American Phytopathological Society
Considerable evidence indicates that $X$. fastidiosa regulates both virulence to plants and its ability to be acquired by insect vectors via its production of one or more fatty acid signal molecules known as DSF, whose production is dependent on regulation of pathogenicity factors ( $r p f$ ) gene, $r p f F$. The identity of the DSF molecule or molecules made by $X$. fastidiosa, while currently unknown, is likely similar but probably different from those made by Xanthomonas spp. because a Xanthomonas campestris pv. campestris DSF biosensor strain recognizes DSF produced by $X$. fastidiosa, although weakly $(10,41)$. DSF in Xanthomonas campestris pv. campestris has recently been shown to consist of three closely related unsaturated fatty acids, each of which has at least some ability to act as a signal molecule capable of inducing the expression of an eng:gfp reporter gene in Xanthomonas campestris pv. campestris (29). In both pathogens, the several genes associated with DSF production and sensing ( $r p f$ ) have high homology and are organized in clusters, although in $X$. fastidiosa, two genes, $r p f A$ and $r p f B$, are located elsewhere in chromosome. Other components of the signaling pathway in Xanthomonas campestris pv. campestris have been characterized $(16,18,31)$ but only $r p f B, r p f F$, and $r p f C$ have been studied in detail in X. fastidiosa. The role of these proteins in X. fastidiosa is apparently similar to that in Xanthomonas campestris pv. campestris, with RpfB presumably altering the substrate pools used by RpfF for synthesis of DSF $(1,41)$ and RpfC being part of a putative two-component regulator that senses DSF (10). The DSF-mediated regulation of virulence factors is essential for host plant colonization in Xanthomonas campestris pv. campestris, with $r p f F$ and $r p f B$ associated with DSF production (5) and $r p f C$ and $r p f G$ with signal perception and transduction $(16,18,30,31)$, leading to downstream control of gene transcription via modulation of cyclic di-GMP levels. In contrast to Xanthomonas campestris pv. campestris, rpfF mutants in $X$. fastidiosa exhibit dramatically increased virulence to plants (41). In addition to suppressing $X$. fastidiosa colonization of plants, DSF is required for its 
colonization of insect vectors, an essential component of the disease cycle (41). Cells must attach to and colonize the cuticular surface of specific regions of the vector foregut, forming microcolonies that eventually develop into mature biofilms of polarly attached cells (2). A DSF-deficient mutant was not able to colonize the foregut of vectors and was not transmissible to plants (41).

Although numerous genes with various functions were identified to be controlled by RpfF in Xanthomonas campestris pv. campestris (30), Xanthomonas citri subsp. citri (27), and Xanthomonas oryzae pv. oryzae (9), relatively little is known about the genes that are dependent on RpfF in $X$. fastidiosa. Afimbrial adhesins such as hemagglutinin-like proteins (Hxfs) are under DSF regulation and are important for cell attachment to vectors $(36,37)$. Afimbrial adhesins are generally upregulated by DSF, suggesting that, when $X$. fastidiosa reaches high local densities in host plants, there is a restriction of further migration of cells within the plant; however, such cells are facilitated in their adhesion to insect vectors $(25,37)$. In contrast, some genes that would facilitate movement of the pathogen and growth in plants such as those conferring production of pili and extracellular enzymes are upregulated in the absence of DSF (10) and do not appear to be essential for vector transmission (37), suggesting that cell-to-cell signaling coordinates the complex life style of this bacterium (10). Because the traits that would contribute to insect colonization by $X$. fastidiosa seem to conflict with plant colonization, spatially structured cells of $X$. fastidiosa may occur within xylem vessels, and the dichotomous characteristics of these phenotypic states may be regulated by differential accumulation of DSF (8).

Although RpfF clearly has a major impact on the behavior of $X$. fastidiosa, we still lack insight into what constitutes virulence factors in such a pathogen besides those few extracellular enzymes and cell surface features that have been examined (8). Thus, in this study, we performed global transcriptional profiling by designing a whole-genome Agilent DNA microarray to more fully identify those traits in $X$. fastidiosa that influence the interactions of the pathogen with plants and insects that are dependent on rpfF and, thus, cell-to-cell signaling.

\section{MATERIALS AND METHODS}

Bacterial strains and growth conditions. Wild-type (WT) strain $X$. fastidiosa Temecula (American Type Culture Collection number 700964) and an isogenic $r p f F$ mutant (41) were grown at $28^{\circ} \mathrm{C}$ in PW liquid media $(33,41)$ with shaking at $160 \mathrm{rpm}$. The rpfF mutant was confirmed to grow in media containing kanamycin $(50 \mu \mathrm{g} / \mathrm{m})$ (Sigma-Aldrich, St. Louis) but was grown without antibiotics for transcriptome analysis.

Microarray design. A DNA microarray containing sequences for all open reading frames (ORFs) in both the genome and plasmid of $X$. fastidiosa was designed using eArray (Agilent Technologies, Santa Clara CA). Briefly, $\leq 10$ probes with a length of 60 nucleotides were designed for each of 2,058 ORFs. Some target sequences had $<10$ probes because of short sequence length or inappropriate base composition. In all, 100 negative probes sharing no similarity with $X$. fastidiosa sequences but, having good temperature and BC scores, were designed based on either Escherichia coli or Arabidopsis thaliana gene sequences. The probes were printed in 105-k $\times 2$ multiplex format to reduce the variation within arrays at Agilent Technologies following their standard procedure. In total, 76,788 tiling probes were also included in this array to cover the whole genome and were not used in this current expression analysis of the RpfF regulon. In addition, this array also contained probes for genes of $X$. fastidiosa strain 9a5c.

RNA isolation. RNA was isolated using an RNeasy Mini Kit (Qiagen Inc., Valencia, CA). Cells were pelleted directly into
RNAprotect Bacteria Reagent (Qiagen Inc.) 6 days after inoculation. For inoculation in PW broth media, initial concentration (optical density at $600 \mathrm{~nm}\left[\mathrm{OD}_{600}\right]=0.05$ ) of WT and $r p f F$ strains were used. Contaminating DNA was digested with a TURBO DNA-free Kit (Ambion, Austin, TX). RNA concentration was determined with a NanoDrop Spectrophotometer (NanoDrop Technologies, Inc.) and sample quality was assessed using an Agilent 2100 Bioanalyzer (Agilent Technologies).

Microarray analysis. Labeled cDNA was generated using the Agilent Two-Color Microarray-Based Prokaryote Analysis kit (Fairplay III labeling; Agilent Technologies). cDNA synthesized from $5 \mu \mathrm{g}$ of total RNA using AffinityScript $\mathrm{HC}$ and random primers was then labeled with either cy3 or cy5 and purified following the manufacturer's instructions. A total of $825 \mathrm{ng}$ of labeled cDNA per sample was used in hybridizations on each microarray. A dye swap was performed to reduce any bias from the labeling dyes. Two biological replicates were used for this study. Hybridization was performed in an oven for $17.5 \mathrm{~h}$ at $65^{\circ} \mathrm{C}$ using a Gene Expression Hybridization Kit (Agilent Technologies) according to the user's manual. The arrays were washed using the manufacturer's recommended protocols and scanned using a dual-laser DNA microarray scanner (Model G2505C; Agilent Technologies). Fluorescence intensities of each element were extracted from the scanned image using Feature Extraction 10.1.1.1 software (Agilent Technologies).

Data preprocessing and differential expression analyses of mean signals provided by the Agilent Feature Extraction were done using the Bioconductor Limma package (51). Data were first normalized within the array by Lowess algorithm (58), then normalized between arrays using a quantile approach. Probe-level expression values were summarized into gene-level signal data. A model-based cluster analysis approach was applied to normalized data to assign detection calls based on negative control probe information. Probe sets lacking detection calls were removed in all the samples before further analysis. For differential expression analysis, the expression value for each gene was fit to a linear model to assess the significance of the difference between mutant and WT strains. Limma applies empirical Bayes methods to construct moderated statistics and incorporates statistical tools to adjust for the multiplicity of the tests (51). The Benjamini and Hochberg approach was used to compute the false discovery rate (FDR). Only protein coding genes were subjected for further analysis. The J. Craig Venter Institute (JCVI) database was used to group the RpfF-dependent regulon into different role categories.

All data from transcriptome experiments as well as experimental protocols used are available from Gene Expression Omnibus datasets, the National Center of Biotechnology Information (accession number GSE38469).

Quantitative reverse-transcription polymerase chain reaction. Quantitative reverse-transcription polymerase chain reaction (QRT-PCR) assays were conducted as described previously (26) using either an ABI 7500 or 7300 system (Applied Biosystems, Inc., Foster City, CA). Primers used in this study were designed using Lasergene v8.1 (DNAstar, Madison, WI). The dna $Q$ encoding the $\varepsilon$ subunit of DNA polymerase III was used as an endogenous control. Values of fold change of QRT-PCR were means of four replicates. Experiments were repeated twice with similar results and only one representative result was presented. The $\Delta \Delta$ cycle threshold method was used to calculate the fold change and standard error as described previously (39).

\section{RESULTS}

Identification of genes controlled by cell-to-cell signaling in PW broth medium. Genes of $X$. fastidiosa that are regulated in an $r p f F$-dependent manner were determined by global transcriptional profiling of cells recovered from relatively dense 
cultures in broth media. We reasoned that liquid medium (PW) better simulates the aqueous environment that $X$. fastidiosa encounters in the xylem than a solidified medium. As in previous studies, it was noted that the WT strain of $X$. fastidiosa formed a thick aggregative ring at the air/liquid interface of culture flasks that was much more pronounced after 14 days of growth than for the rpfF mutant (Supplementary Figure 1). The total population size of the two strains (sum of both planktonic and attached cells), however, was similar at a given sampling time. Aggregates of cells were also noted within the cultures, particularly for the $r p f F$ mutant, but these dispersed after $\approx 11$ days of incubation. Thus, transcript abundance was assessed on the total bacterial community recovered from culture flasks using an Agilent DNA microarray constructed for strain Temecula, which consisted of $\leq 1060$-bp probes for each of the 2,058 ORFs of this strain.

In total, 446 protein coding genes whose expression was significantly different between the WT and the $r p f F$ mutant (FDR $<0.05$ ) were identified when cells were grown in PW liquid medium for 6 days with initial concentration of $\mathrm{OD}_{600}=0.05$. Among them, 165 genes were downregulated in the $r p f F$ mutant compared with the WT strain whereas 281 genes were overexpressed at least twofold in the $r p f F$ mutant compared with the WT strain (Supplementary Table 1). The expression of 247 of these genes differed by $>2.5$-fold between the WT and the rpfF mutant. Of these, 150 were more highly expressed in the rpfF mutant than in the WT while 97 were expressed at a lower level. These $r p f F$-dependent genes clearly were involved in many cellular processes because they could be assigned to 20 functional categories according to the annotation from the JCVI role categories, including biosynthesis of cofactors, prosthetic groups, and carriers; cell envelope; cellular processes; signal transduction; metabolism of purines, pyrimidines, nucleosides, and nucleotides; DNA metabolism; energy metabolism; fatty acid and phospholipid metabolism; mobile and extrachromosomal element functions; protein fate; protein synthesis; regulatory functions; transcription; transport and binding proteins; and hypothetical proteins (Supplementary Figure 2). Interestingly, RpfF function was required for regulation of 11 regulatory and $\sigma$ factors, including $r p f E$ (PD0401), yybA(PD0595), PD1177, $g \ln B$ (PD1025), rpfG (PD0405), PD0954, PD0199, PD2050, colR (PD1919), rpoH (PD2048), and rpoD (PD0593).

Although many of the genes of $X$. fastidiosa that are most strongly regulated in an $r p f F$-dependent manner had no obvious direct connection to virulence or insect transmission, a number of genes whose expression was less strongly dependent on RpfF $(P \leq 0.05)$ that might have such a connection were found (Table 1). In total, 61 confirmed or putative virulence genes that differed in expression between a WT and $r p f F$ mutant $(P \leq 0.05)$ were identified (Table 1). Of these, 18 genes were downregulated and 43 genes were upregulated in the $r p f F$ mutant compared with the WT strain. Among those genes upregulated in the $r p f F$ mutant were the regulatory genes csrA (PD0095), xrvA (PD1905), fur (PD1374), PD0708, and pilH (PD1632), in addition to the 11 regulatory genes mentioned above. In addition, 4 colicin V-related genes, 4 gum genes, 11 type IV pili genes, and 1 type I pilus gene $m r k D$ were more highly expressed in the $r p f F$ mutant compared with the WT strain. The downregulated genes in the rpfF mutant compared with the WT consist of four hemagglutinin genes (including $h x f A$ and $h x f B$ ), two hemolysin genes, and yegN, which encodes an acriflavin resistance protein (Table 1).

Confirmation of microarray data using QRT-PCR. In general, estimates of relative RNA abundance for a given gene made using DNA microarrays were confirmed using QRT-PCR. The $r p f F$-dependent expression of 24 genes was determined using both methods. Similar ratios of expression of 22 of the 24 genes in the WT strain and the rpfF mutant were obtained by both methods (Table 2).

\section{DISCUSSION}

Given the large number of genes that exhibit $r p f F$-dependent patterns of expression in this study, it is clear that DSF-mediated signaling plays a central role in the context-dependent behavior of $X$. fastidiosa. RpfF-mediated signaling influences a much larger number of genes (a total of 446 protein coding genes with an FDR $<0.05$, and even as many as 247 genes with both an FDR $<$ 0.05 and a fold change $>2.5$ ) than other regulators, including GacA (27 genes), AlgU (43 genes), RpoN (38 genes), and RpoE (21 genes) $(14,15,48,49)$. Given that it controls the expression of several central regulatory genes and $\sigma$ factors, including rpfE (PD0401), $y y b A(\mathrm{PD} 0595), \mathrm{PD} 1177, g \ln B$ (PD1025), $r p f G$ (PD0405), PD0954, PD0199, PD2050, colR (PD1919), rpoH (PD2048), and $r p o D$ (PD0593) (FDR < 0.05), at least some of the regulon of the $r p f$ system may be due to such secondary regulators. Under the less-stringent requirements for differential gene expression $(P \leq$ 0.05), the additional regulatory genes csrA (PD0095), $x r v A$ (PD1905), fur (PD1374), PD0708, and pilH (PD1632) were also found to be regulated by DSF (Table 1). Thus, DSF-mediated signaling seems to be tightly linked with other regulators to enable complex patterns of context-dependent gene expression to be employed by $X$. fastidiosa in the different habitats that it colonizes.

Many of the $r p f F$-dependent genes found in $X$. fastidiosa have been studied only in other related pathogens such as Xanthomonas campestris pv. campestris and Xanthomonas citri; hence, their roles in X. fastidiosa remain unclear. ColR, MarR, PilH, Fur, XrvA, and RpfG have all been reported to be involved in the regulation of virulence genes in other pathogens $(20,46,54,60)$. ColR is a global regulator involved in virulence, hypersensitive response, and stress tolerance of Xanthomonas campestris pv. campestris and $X$. axonopodis pv. citri $(57,60)$. Members of the MarR family such as HpaR were reported to be involved in pathogenesis, hypersensitive response, and extracellular protease production in Xanthomonas campestris pv. campestris (54). xrvA, encoding an H-NS-like protein in $X$. oryzae pv. oryzae, contributes to its virulence, because a knockout mutant exhibited a significant reduction in virulence to rice (20). Disruption of RpfG, involved in the DSF signal transduction system along with RpfC and $\mathrm{RpfF}$, led to reduced expression of virulence functions such as extracellular enzymes, biofilm structure, and motility in Xanthomonas campestris pv. campestris (46) and reduced virulence in $X$. citri (27). PilH is a regulator of type IV pili (13) and expression of type IV pili contributes to virulence of Acetovorax avenae subsp. citrulli (4). Type IV pili are essential for twitching motility and, thus, active movement of $X$. fastidiosa in xylem vessels and various pil mutants are less virulent to grape $(38,40)$. Fur is central to the regulation of iron homeostasis and is required for full virulence of many bacteria, including Bacillus cereus (28), Erwinia chrysanthemi (22), and X. oryzae pv. oryzae (53), and DSF signaling in $X$. oryzae pv. oryzae has been linked to iron metabolism (9). Thus, the context-dependent expression of the homologs of these virulence regulators in $X$. fastidiosa might be expected to be involved in controlling expression of those traits that are appropriate for its solely vascular existence and, perhaps, also of its colonization of the surface of insect mouthparts.

Attachment and biofilm formation are the most coherent virulence phenotypes that are RpfF-dependent. A large collection of genes that lead to the adhesiveness of $X$. fastidiosa, including those encoding hemagglutinins ( $h x f A$ and $h x f B)$, were expressed at a lower level in the $r p f F$ mutant. In contrast, 11 type IV pili genes and 4 gum genes were expressed at higher levels than in the WT strain (Table 1). Thus, this study extends the initial reports of the regulation of these traits seen in earlier studies $(10,37)$. In general, the patterns of expression of the genes involved in adhesion and motility are consistent with a model proposed by Chatterjee et al. (8) that describes a radical shift in the traits 
expressed by $X$. fastidios $a$ as it transitions from a plant exploratory phase to a more adhesive form that is capable of being vectored by insects. This model accounts for the hypervirulence of $r p f F$ mutants that, in turn, are incapable of colonizing insects and, thus, of being transmitted, highlighting that the traits that allow movement through the plant are incompatible with insect transmission. In aggregate, nearly all of the genes that would encode structures or molecules that would tend to cause cells to adhere to surfaces were upregulated in a WT strain compared with the rpfF mutant. The lower expression of this suite of ad- hesins in an rpfF mutant also accounts for the fact that it is reduced in biofilm formation and attachment to flasks. That is, downregulation of the hemagglutinin genes would lead to less attachment and thus biofilm formation. Higher expression of type IV pili genes, which are involved in twitching motility (40), in an $r p f F$ mutant accounts for its increased movement and colonization of plants (10). Previous studies linked Pierce's disease symptom development with the rate and extent of $X$. fastidiosa colonization of the xylem $(23,34,44)$. The finding of downregulation of the suite of hemagglutinin genes in an $r p f F$ mutant is consistent with

TABLE 1. Relative expression of putative virulence genes of a wild-type strain and an $r p f F$ mutant of Xylella fastidiosa

\begin{tabular}{|c|c|c|c|}
\hline Locus tag & Product name & Ratio (Mut/WT) & $P$ value \\
\hline PD0215 & Colicin V precursor & 9.12 & $1.30 \mathrm{E}-14$ \\
\hline PD0216 & Colicin V precursor & 7.89 & $5.96 \mathrm{E}-13$ \\
\hline PD0895 & Outer membrane protein P6 precursor & 4.23 & $5.02 \mathrm{E}-07$ \\
\hline PD1632 & PilH family regulatory protein & 3.38 & $2.21 \mathrm{E}-05$ \\
\hline PD0496 & Colicin V secretion protein & 3.29 & $3.24 \mathrm{E}-05$ \\
\hline PD0283 & DnaK suppressor & 3.23 & 4.45E-05 \\
\hline PD0146 & Outer membrane protein & 3.06 & $9.62 \mathrm{E}-05$ \\
\hline PD1923 & Fimbrial assembly protein & 2.92 & $1.85 \mathrm{E}-04$ \\
\hline PD0852 & Colicin V production protein & 2.90 & $2.09 \mathrm{E}-04$ \\
\hline PD0708 & Virulence regulator & 2.70 & $5.45 \mathrm{E}-04$ \\
\hline PD0855 & VirK protein & 2.69 & $5.73 \mathrm{E}-04$ \\
\hline PD0845 & Pilus protein & 2.64 & 7.23E-04 \\
\hline PD0405 & Response regulator & 2.53 & 0.001 \\
\hline PD0012 & Biopolymer transport ExbD2 protein & 2.46 & 0.002 \\
\hline PD1691 & Fimbrial assembly protein & 2.44 & 0.002 \\
\hline PD1393 & GumE protein & 2.43 & 0.002 \\
\hline PD0058 & Fimbrial adhesin precursor & 2.40 & 0.002 \\
\hline PD0757 & Peptidoglycan-associated outer membrane lipoprotein precursor & 2.36 & 0.003 \\
\hline PD0846 & Pilus biogenesis protein & 2.31 & 0.003 \\
\hline PD1279 & DnaJ protein & 2.21 & 0.01 \\
\hline PD1682 & Outer membrane hemin receptor & 2.21 & 0.01 \\
\hline PD1395 & GumC protein & 2.13 & 0.01 \\
\hline PD0234 & Aconitate hydratase & 2.11 & 0.01 \\
\hline PD1807 & Outer membrane protein & 2.10 & 0.01 \\
\hline PD0755 & cAMP-regulatory protein & 2.10 & 0.01 \\
\hline PD0011 & Biopolymer transport ExbD1 protein & 2.08 & 0.01 \\
\hline PD0024 & PilE protein & 2.07 & 0.01 \\
\hline PD1147 & Twitching motility protein & 2.01 & 0.01 \\
\hline PD0233 & Putative long-chain fatty acyl CoA ligase & 2.00 & 0.02 \\
\hline PD1924 & Fimbrial protein & 1.96 & 0.02 \\
\hline PD1374 & Ferric uptake regulator & 1.95 & 0.02 \\
\hline PD1709 & Outer membrane protein & 1.94 & 0.02 \\
\hline PD1905 & Virulence regulator & 1.93 & 0.02 \\
\hline PD1396 & GumB protein & 1.91 & 0.02 \\
\hline PD1148 & Twitching motility protein & 1.90 & 0.02 \\
\hline PD1611 & Fimbrial assembly protein & 1.88 & 0.03 \\
\hline PD0369 & Proteic killer active protein & 1.88 & 0.03 \\
\hline PD1392 & GumF protein & 1.88 & 0.03 \\
\hline PD1735 & Type 4 fimbrial biogenesis protein & 1.88 & 0.03 \\
\hline PD1981 & TonB protein & 1.84 & 0.03 \\
\hline PD0095 & Carbon storage regulator & 1.84 & 0.03 \\
\hline PD0125 & Cysteine protease & 1.79 & 0.04 \\
\hline PD0143 & Hemolysin III protein & 1.77 & 0.05 \\
\hline PD2110 & Hemagglutinin-like secreted protein & 0.58 & 0.05 \\
\hline PD0843 & TonB protein & 0.57 & 0.05 \\
\hline PD0020 & Pre-pilin leader sequence & 0.55 & 0.04 \\
\hline PD1403 & Acriflavin resistance protein D & 0.54 & 0.03 \\
\hline PD0536 & Hemolysin & 0.54 & 0.03 \\
\hline PD1427 & Bacteriocin & 0.53 & 0.03 \\
\hline PD2112 & Hypothetical protein PD2112 & 0.52 & 0.02 \\
\hline PD1506 & Hemolysin-type calcium binding protein & 0.51 & 0.02 \\
\hline PD2114 & Hypothetical protein PD2114 & 0.49 & 0.01 \\
\hline PD2118 & Hemagglutinin-like secreted protein & 0.48 & 0.01 \\
\hline PD1589 & TonB-dependent receptor & 0.46 & 0.01 \\
\hline PD1554 & Hypothetical protein PD1554 & 0.42 & 0.003 \\
\hline PD1517 & Hypothetical protein PD1517 & 0.41 & 0.002 \\
\hline PD1787 & Hypothetical protein PD1787 & 0.38 & $6.63 \mathrm{E}-04$ \\
\hline PD1792 & Hemagglutinin-like protein & 0.38 & $6.36 \mathrm{E}-04$ \\
\hline PD0986 & Hemagglutinin-like secreted protein & 0.35 & $2.17 \mathrm{E}-04$ \\
\hline PD2108 & Hypothetical protein PD2108 & 0.33 & 8.97E-05 \\
\hline PD1790 & Hypothetical protein PD1790 & 0.28 & $9.87 \mathrm{E}-06$ \\
\hline
\end{tabular}

a FC: fold change of gene expression; Mut: rpfF mutant of $X$. fastidiosa; WT: wild-type strain of $X$. fastidiosa. 
the demonstration of these genes as encoding antivirulence traits (25).

The RpfF regulon of $X$. fastidiosa is apparently quite different from that of Xanthomonas campestris pv. campestris, even though they do share some similarity. Many of the homologous genes that are regulated by RpfF in all of these species exhibit different patterns of regulation. For example, among the 165 RpfF-dependent genes identified in Xanthomonas campestris pv. campestris (30), 91 have homologues in X. fastidiosa, 7 have a similar trend in expression, and 26 have an opposite trend, while 58 are not regulated by $\mathrm{RpfF}$ in $X$. fastidiosa. RpfF positively regulates expression of genes encoding chemotaxis (cheY), iron uptake (ton $B)$, drug resistance (ftsL and $a c r D)$, transcription regulation (slyA and PD0747) and fatty acid metabolism (phaF) in both species. However, RpfF negatively regulates Gum genes and pil genes in $X$. fastidiosa while the opposite is true in Xanthomonas campestris pv. campestris or $X$. citri $(27,30)$. Other examples of genes that show opposite patterns of regulation include exbDl and exbD2, which are involved in iron uptake; $a h p F$, involved in oxidative stress resistance; and genes encoding ribosomal proteins (rpsC, rpsD, rpsL, rpsO, rpsS, rplE, rplP, and PD0125); genes involved in the TCA cycle ( $s u c C$, $s u c D, s d h C$, and $s d h D)$; genes involved in respiration (cyoA, cyoC, and $c y o D)$; genes encoding membrane components and transporters $(a t p B$, atpE, and $a t p F)$; and the hypothetical gene PD0710.

The different patterns of regulation might be facilitated by structural differences in the rpf clusters of $X$. fastidiosa and Xanthomonas campestris pv. campestris. The rpf cluster of Xanthomonas campestris pv. campestris contains 16 genes whereas the $X$. fastidiosa rpf cluster consists of only 12 genes. Both $r p f H$ and rpfI are not present in X. fastidiosa. RpfH is structurally related to the sensory input domain of RpfC while RpfI positively regulates the synthesis of proteases, endoglucanases, and EPS in Xanthomonas campestris pv. campestris $(19,50)$. Likewise, $r p f B$, which is involved in DSF synthesis by apparently modulating the mixture of chemical species of DSF that are produced by these species $(1,29)$, is located elsewhere in the chromosome of $X$. fastidiosa, and is not linked transcriptionally with rpfF as in Xanthomonas campestris pv. campestris.
There is some evidence that the different chemical forms of DSF produced by $X$. fastidiosa each lead to somewhat different patterns of gene expression (1). Thus, the unlinking of $r p f F$ and $r p f B$ expression in $X$. fastidiosa may enable a more nuanced pattern of DSF signaling to occur compared with Xanthomonas campestris pv. campestris, which could explain the substantial differences in the rpfF regulon in these two species. The opposite patterns of RpfF-dependent expression of a variety of virulence genes clearly explain why the $r p f F$ mutants of $X$. fastidiosa are hypervirulent whereas those of other Xanthomonads are less virulent $(5,27,41)$. As noted above, the lifestyle of $X$. fastidiosa, which colonizes both xylem vessels and the mouthparts of insects, is both more complex and different from that of other Xanthomonads that are restricted to the vasculature of plants; thus, it would be expected that it would need to employ different behaviors to colonize these two habitats compared with pathogens such as Xanthomonas campestris pv. campestris and Xanthomonas citri. In addition, differences in the test conditions (e.g., time points and media) might also contribute to the different patterns of regulation of $X$. fastidiosa and Xanthomonas campestris pv. campestris.

A variety of genes whose linkage to virulence of $X$. fastidiosa is less clear are also controlled by RpfF. At least three hemolysinrelated genes were dependent on RpfF for proper expression (Table 1). Hemolysin is a member of a protein family that includes pore-forming toxins and has been implicated in bacterial virulence (32). However, its role in virulence of $X$. fastidiosa is unclear and needs further characterization. Curiously, the hemolysins encoded by PD0536 and PD1506 are upregulated by RpfF whereas that of PD0143 is downregulated (Table 1), suggesting that any role that they play may occur at different stages of the infection process, or at least in cells differing in local cell density. The expression of PD1517, encoding a homolog of invasionassociated protein $\mathrm{P} 60$, is upregulated in the presence of RpfF. P60 homologs are major extracellular proteins involved in the invasion of pathogens into their host cell, functioning as a presumptive murein hydrolase and host-membrane binding protein in Listeria spp. (42). Four genes encoding colicin V-related proteins were suppressed by RpfF (Tables 1 and 2). In fact, these genes were among those most highly suppressed in the presence of

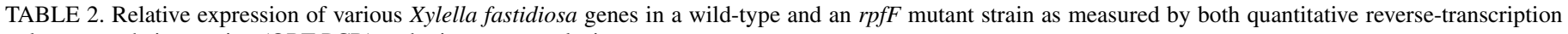
polymerase chain reaction (QRT-PCR) and microarray analysis

\begin{tabular}{|c|c|c|c|c|}
\hline \multirow[b]{2}{*}{ Locus tag } & \multirow[b]{2}{*}{ Name } & \multicolumn{2}{|c|}{ Average FC (Mut/WT) $)^{\mathrm{a}}$} & \multirow[b]{2}{*}{ Function } \\
\hline & & QRT-PCR (mean \pm SD) & Microarray & \\
\hline $16 \mathrm{~S}$ & $16 S$ & $1.38 \pm 0.13$ & ND & 16S rRNA \\
\hline PD0001 & $\operatorname{dnaA}$ & $1.55 \pm 0.04$ & 4.72 & Chromosomal replication initiator \\
\hline PD0019 & fimT & $1.17 \pm 0.04$ & ND & Pre-pilin like leader sequence \\
\hline PD0024 & pile & $1.88 \pm 0.21$ & 2.07 & PilE protein \\
\hline PD0062 & fimA & $0.88 \pm 0.06$ & ND & Fimbrial subunit precursor \\
\hline PD0216 & $\ldots$ & $1.89 \pm 0.06$ & 7.89 & Colicin V precursor \\
\hline PD0313 & $\operatorname{pspB}$ & $1.07 \pm 0.11$ & ND & Serine protease \\
\hline PD0406 & $r p f C$ & $2.67 \pm 0.16$ & ND & Regulator of pathogenicity factors \\
\hline PD0496 & $c v a A$ & $1.93 \pm 0.37$ & 3.29 & Colicin V secretion protein \\
\hline PD0593 & rpoD & $1.91 \pm 0.12$ & 3.72 & RNA polymerase $\sigma-70$ factor \\
\hline PD0852 & $\ldots$ & $1.62 \pm 0.16$ & 2.9 & Colicin V production protein \\
\hline PD1485 & pglA & $0.86 \pm 0.12$ & ND & Polygalacturonase precursor \\
\hline PD1611 & pilY1 & $2.96 \pm 0.47$ & 1.88 & Fimbrial assembly protein \\
\hline PD1632 & pilH & $2.06 \pm 0.05$ & 3.38 & Regulatory protein pilH family \\
\hline PD1672 & bfr & $2.18 \pm 0.12$ & 4.15 & Bacterioferritin \\
\hline PD1691 & pilQ & $1.41 \pm 0.09$ & 2.44 & Fimbrial assembly protein \\
\hline PD1792 & pspA & $0.63 \pm 0.03$ & 0.38 & Hemagglutinin-like protein \\
\hline PD1851 & engXCA & $0.53 \pm 0.08$ & ND & Endo-1,4-beta-glucanase \\
\hline PD1856 & engXCA & $0.85 \pm 0.13$ & ND & Extracellular endoglucanase \\
\hline PD1919 & colR & $1.77 \pm 0.14$ & 3.34 & Two-component system, regulatory protein \\
\hline PD1922 & pilD & $1.38 \pm 0.23$ & ND & Pre-pilin leader peptidase \\
\hline PD1923 & pilc & $2.44 \pm 0.12$ & 2.92 & Fimbrial assembly protein \\
\hline PD1960 & $\operatorname{rps} B$ & $0.64 \pm 0.06$ & ND & $30 \mathrm{~S}$ ribosomal protein $\mathrm{S} 2$ \\
\hline PD2048 & rpoH & $3.10 \pm 0.55$ & 5.45 & RNA polymerase $\sigma-32$ factor \\
\hline
\end{tabular}

a FC: fold change of gene expression; Mut: rpfF mutant of $X$. fastidiosa; WT: wild-type strain of $X$. fastidiosa. SD: standard deviation; ND: no difference. 


\begin{tabular}{|c|c|c|c|c|c|c|c|c|c|c|c|}
\hline & $\begin{array}{l}\text { Gene } \\
\text { name }\end{array}$ & ORFs & $r p f F / W T$ & HIC & LIC & $\begin{array}{c}\text { 3G10R/ } \\
\text { PW }\end{array}$ & $\begin{array}{c}\text { Gomesin/no } \\
\text { gomesin }\end{array}$ & $\begin{array}{c}\text { gacA/ } \\
\mathrm{WT}\end{array}$ & $\begin{array}{l}\text { rpoNI } \\
\text { WT }\end{array}$ & $\begin{array}{l}\text { Heat shock/ } \\
\text { control }\end{array}$ & $\begin{array}{l}\text { Pathogenic/ } \\
\text { nonpathogenic } \\
\text { condition }\end{array}$ \\
\hline \multirow{2}{*}{$\begin{array}{l}\text { Immunity protein } \\
\text { Precursor }\end{array}$} & $c v i$ & PD0214 & $\mathrm{NC}$ & Up & Up & $\ldots$ & $\ldots$ & $\ldots$ & $\ldots$ & $\ldots$ & $\ldots$ \\
\hline & $c v a C$ & $\begin{array}{r}\text { PD0215, } \\
\text { PD0216 }\end{array}$ & Up & Up & Up & $\mathrm{Up}, \mathrm{NC}$ & Up & $\ldots$ & Up, down & Down & Up \\
\hline Secretion protein & $c v a A$ & PD0496 & Up & Up & $\ldots$ & $\ldots$ & Up & $\ldots$ & $\ldots$ & Down & $\ldots$ \\
\hline $\mathrm{ABC}$ transporter & $c v a B$ & PD0499 & $\mathrm{NC}$ & Up & $\ldots$ & $\ldots$ & $\ldots$ & $\ldots$ & $\ldots$ & $\ldots$ & $\ldots$ \\
\hline Production protein & $c v p A$ & PD0852 & Up & $\ldots$ & $\ldots$ & $\ldots$ & $\ldots$ & $\ldots$ & Up & $\ldots$ & $\ldots$ \\
\hline Reference & $\ldots$ & $\ldots$ & This study & 59 & 59 & 11 & 21 & 49 & 15 & 14 & 17 \\
\hline
\end{tabular}

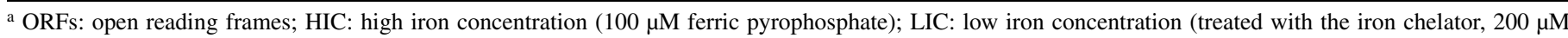
2,2'-dipyridyl); WT: wild type; NC: no change.

TABLE 4. Expression of Xylella fastidiosa genes encoding gum, hemagglutinin, and hemolysin under different conditions ${ }^{\mathrm{a}}$

\begin{tabular}{|c|c|c|c|c|c|c|c|c|}
\hline Locus tag & Name & Function & $\begin{array}{l}r p f F / \\
\text { WT }\end{array}$ & $\begin{array}{l}\text { Gomesin treated/ } \\
\text { nontreated }\end{array}$ & $\begin{array}{c}g a c A / \\
\text { WT }\end{array}$ & $\begin{array}{l}\text { Heat shock/ } \\
\text { control }\end{array}$ & HIC & LIC \\
\hline PD1396 & gumB & GumB protein & Up & $\ldots$ & $\ldots$ & $\ldots$ & $\ldots$ & $\ldots$ \\
\hline PD1395 & gumC & GumC protein & Up & Up & Down & $\ldots$ & $\ldots$ & $\ldots$ \\
\hline PD1394 & gumD & GumD protein & $\mathrm{NC}$ & Up & $\ldots$ & $\ldots$ & $\ldots$ & $\ldots$ \\
\hline PD1393 & gumE & GumE protein & $\mathrm{Up}$ & Up & $\ldots$ & $\ldots$ & $\ldots$ & $\ldots$ \\
\hline PD1392 & gumF & GumF protein & Up & $\ldots$ & $\ldots$ & $\ldots$ & Up & $\ldots$ \\
\hline PD1388 & gumK & GumK protein & $\mathrm{NC}$ & $\ldots$ & $\ldots$ & $\ldots$ & $\ldots$ & $\ldots$ \\
\hline PD1387 & gumM & GumM protein & $\mathrm{NC}$ & $\ldots$ & $\ldots$ & $\ldots$ & Down & Down \\
\hline PD1792 & $h x f B$ & Hemagglutinin-like protein & Down & $\ldots$ & $\ldots$ & Up & $\ldots$ & $\ldots$ \\
\hline PD0986 & pspA & Hemagglutinin-like secreted protein & Down & $\ldots$ & $\ldots$ & $\ldots$ & $\ldots$ & $\ldots$ \\
\hline PD2110 & pspA & Hemagglutinin-like secreted protein & Down & $\ldots$ & $\ldots$ & $\ldots$ & $\ldots$ & $\ldots$ \\
\hline PD2116 & pspA & Hemagglutinin-like secreted protein & $\mathrm{NC}$ & $\ldots$ & $\ldots$ & $\ldots$ & $\ldots$ & $\ldots$ \\
\hline PD2118 & $h x f A$ & Hemagglutinin-like secreted protein & Down & Up & $\ldots$ & Up & $\ldots$ & $\ldots$ \\
\hline PD0536 & tlyC & Hemolysin & Down & $\ldots$ & $\ldots$ & $\ldots$ & $\ldots$ & $\ldots$ \\
\hline PD1933 & hec $B$ & Hemolysin activation protein & $\mathrm{NC}$ & $\ldots$ & $\ldots$ & $\ldots$ & $\ldots$ & $\ldots$ \\
\hline PD0143 & $\ldots$ & Hemolysin III protein & Up & $\ldots$ & $\ldots$ & $\ldots$ & $\ldots$ & $\ldots$ \\
\hline PD1787 & $\ldots$ & Hemolysin & Down & $\ldots$ & $\ldots$ & Up & $\ldots$ & $\ldots$ \\
\hline PD1790 & $\ldots$ & Hemolysin & Down & $\ldots$ & $\ldots$ & $\ldots$ & $\ldots$ & $\ldots$ \\
\hline PD2108 & $\ldots$ & Hemolysin & Down & $\ldots$ & $\ldots$ & $\ldots$ & $\ldots$ & $\ldots$ \\
\hline PD2112 & $\ldots$ & Hemolysin & Down & $\ldots$ & $\ldots$ & $\ldots$ & $\ldots$ & $\ldots$ \\
\hline PD2114 & $\ldots$ & Hemolysin & Down & $\ldots$ & $\ldots$ & $\ldots$ & $\ldots$ & $\ldots$ \\
\hline Reference & $\ldots$ & $\ldots$ & This study & 21 & 49 & 14 & 59 & 59 \\
\hline
\end{tabular}

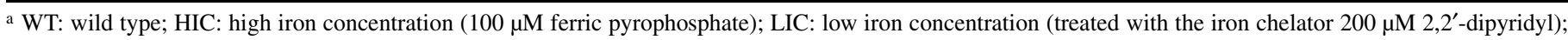
NC: no change.

RpfF. Colicin V has been suggested to play an important role for $X$. fastidiosa by acting as an antimicrobial agent, enabling the colonization of xylem vessels and the insect foregut despite the presence of other endophytic bacteria that have been reported to be present $(3,7,12)$ and which might compete with it in the absence of such a defensive arsenal (59). The negative regulation of colicin $\mathrm{V}$ genes by RpfF signaling suggests that, if colicins play such a role, it is most useful when $X$. fastidiosa populations are low. Presumably once $X$. fastidiosa is well established inside the xylem, competition from other species is less important and, hence, the production of colicins is reduced.

The expression of 19 phage-related genes was at least 2.5 -fold higher in the WT strain compared with the rpfF mutant while the expression of 2 was lower. This suggests that, at high cell populations, most prophage-like regions are activated. Interestingly, a high proportion of phage genes in X. fastidiosa were upregulated when bacteria were placed under stress conditions such as heat shock (14) and nitrogen starvation (15). The activation of phagerelated genes was suggested to trigger induction of the lytic cycle, which ultimately results in the formation of virus-like particles. The activation of phage-related genes by RpfF indicates that they may be preferentially upregulated at high population sizes, a stress condition stimulated by the blockage of the xylem that would typically occur in later stages of infection. A similar induction of virus particles and resultant lysis of bacteria by exogenous AHL signal molecules was observed in a mixed bacterial community recovered from soil (24), suggesting that, although the virus may well have usurped the bacterial signaling pathway to enable escape from cells as they become stressed, the bacterial host might well benefit in some way from enabling such an induction of virus production as well. However, the roles of the phage-related genes are unclear. In addition, RpfF also controls 127 hypothetical genes with unknown functions. Those genes need further characterization to understand how $X$. fastidiosa survives in the nutrient-poor xylem and causes disease.

To determine whether cell density signaling may be integrated with other environmental contexts, the published stimulons and regulons of $X$. fastidiosa in different conditions were compared with that of the RpfF regulon. It is noteworthy that many of the genes that were most strongly regulated in one environmental context, such as those encoding colicin V, type I and IV pili, gum, hemagglutinins, and hemolysins, were also strongly regulated in others (Tables 3 to 5). Interestingly, many pili- and colicin-encoding genes in the RpfF regulon are in common with those in the high iron stimulon. Furthermore, whereas most colicin genes were suppressed by RpfF, they were upregulated in high iron conditions. Likewise, although high iron conditions did not lead to upregulation of all pil genes, those that did exhibit this pattern of expression tended to also be suppressed by RpfF (Tables 3 to 5). Because RpfF function (DSF accumulation) is associated with high bacterial concentrations which would logically be found in blocked xylem vessels, twitching motility would probably be futile and, thus, pil genes are suppressed. The flow of nutrients such as iron through such vessels would also be low. Therefore, the cell might use the higher iron levels expected in vessels that are not heavily colonized as a cue for exploratory twitching motility. RpfF signaling may reinforce the lack of this cue. However, such a model needs further investigation. 


\begin{tabular}{|c|c|c|c|c|c|c|c|c|}
\hline PD & Function & Name & $\begin{array}{c}r p f F / \\
\text { WT }\end{array}$ & $\mathrm{HIC}$ & LIC & $\begin{array}{c}\text { rpoN/ } \\
\text { WT }\end{array}$ & $\begin{array}{c}\text { Gomesin/c } \\
\text { ontrol }\end{array}$ & $\begin{array}{c}g a c A / \\
\text { WT }\end{array}$ \\
\hline PD0019 & Pili retraction protein PilT & fimT & $\mathrm{NC}$ & $\ldots$ & $\ldots$ & $\ldots$ & $\ldots$ & $\ldots$ \\
\hline PD0020 & Pre-pilin leader sequence & pilV & Down & $\ldots$ & Down & $\ldots$ & $\ldots$ & $\ldots$ \\
\hline PD0021 & Hypothetical membrane associated protein & $\ldots$ & $\mathrm{NC}$ & $\ldots$ & $\ldots$ & $\ldots$ & $\ldots$ & $\ldots$ \\
\hline PD0022 & Pili assembly protein PilX & pilX & $\mathrm{NC}$ & $\ldots$ & $\ldots$ & $\ldots$ & $\ldots$ & $\ldots$ \\
\hline PD0023 & Pili assembly protein PilY1 & pilY1 & $\mathrm{NC}$ & $\ldots$ & $\ldots$ & $\ldots$ & $\ldots$ & $\ldots$ \\
\hline PD0024 & Pili membrane scaffold protein PilE & pile & Up & $\ldots$ & Down & $\ldots$ & $\ldots$ & $\ldots$ \\
\hline PD0058 & Type-1 fimbrial protein, a chain precursor & $m r k D$ & Up & $\ldots$ & $\ldots$ & $\ldots$ & $\ldots$ & $\ldots$ \\
\hline PD0060 & Outer membrane usher protein FimC & $\operatorname{fim} C$ & $\mathrm{NC}$ & Down & Down & $\ldots$ & $\ldots$ & $\ldots$ \\
\hline PD0061 & Chaperone protein EcpD & ecpD & $\mathrm{NC}$ & $\ldots$ & $\ldots$ & $\ldots$ & $\ldots$ & $\ldots$ \\
\hline PD0062 & Major pilin protein FimA & $\operatorname{fim} A$ & $\mathrm{NC}$ & Down & Down & Up & $\ldots$ & $\ldots$ \\
\hline PD0502 & Pili assembly protein PilY1 & pilY1 & $\mathrm{NC}$ & $\ldots$ & $\ldots$ & $\ldots$ & $\ldots$ & $\ldots$ \\
\hline PD0845 & Pili chemotaxis chey homolog PilG & pilG & Up & Up & $\ldots$ & $\ldots$ & $\ldots$ & $\ldots$ \\
\hline PD0846 & Pili chemotaxis CheW homolog PilI & pilI & Up & Up & $\ldots$ & $\ldots$ & $\ldots$ & $\ldots$ \\
\hline PD0847 & Pili methyl chemotaxis protein PilJ & pilJ & $\mathrm{NC}$ & Up & Down & $\ldots$ & $\ldots$ & $\ldots$ \\
\hline PD0848 & Chemotaxis protein CheA & cheA & $\mathrm{NC}$ & $\ldots$ & $\ldots$ & $\ldots$ & $\ldots$ & $\ldots$ \\
\hline PD0849 & Pili chemotaxis protein methylesterase CheB (ec 3.1.1.61) & cheB & $\mathrm{NC}$ & $\ldots$ & $\ldots$ & $\ldots$ & $\ldots$ & $\ldots$ \\
\hline PD1077 & Pili subunit PilA1 & pilA1 & $\mathrm{NC}$ & $\ldots$ & $\ldots$ & $\ldots$ & $\ldots$ & $\ldots$ \\
\hline PD1147 & Pili retraction protein PilT & pilT & Up & Down & $\ldots$ & $\ldots$ & $\ldots$ & $\ldots$ \\
\hline PD1148 & Pili retraction protein PilU & pilU & Up & Down & Down & $\ldots$ & $\ldots$ & $\ldots$ \\
\hline PD1497 & Pili assembly protein PilZ & pilZ & Up & $\ldots$ & $\ldots$ & $\ldots$ & $\ldots$ & $\ldots$ \\
\hline PD1610 & Pili membrane scaffold protein PilE & pile & $\mathrm{NC}$ & $\ldots$ & Down & $\ldots$ & $\ldots$ & $\ldots$ \\
\hline PD1611 & Pili assembly protein PilY1 & pilY1 & Up & $\ldots$ & $\ldots$ & $\ldots$ & $\ldots$ & $\ldots$ \\
\hline PD1612 & Pili assembly protein PilX & pilX & $\mathrm{NC}$ & $\ldots$ & $\ldots$ & $\ldots$ & $\ldots$ & $\ldots$ \\
\hline PD1613 & Pili assembly protein PilW & pilW & $\mathrm{NC}$ & $\ldots$ & $\ldots$ & $\ldots$ & $\ldots$ & $\ldots$ \\
\hline PD1614 & Hypothetical membrane associated protein & $\ldots$ & $\mathrm{NC}$ & $\ldots$ & $\ldots$ & $\ldots$ & $\ldots$ & $\ldots$ \\
\hline PD1615 & Pili retraction protein PilT & pilT & $\mathrm{NC}$ & Down & $\ldots$ & $\ldots$ & $\ldots$ & $\ldots$ \\
\hline PD1623 & PilF protein & pilF & $\mathrm{NC}$ & $\ldots$ & $\ldots$ & $\ldots$ & $\ldots$ & $\ldots$ \\
\hline PD1691 & Pili secretion protein PilQ & pilQ & Up & $\ldots$ & $\ldots$ & $\ldots$ & $\ldots$ & $\ldots$ \\
\hline PD1692 & Pili assembly protein PilP & pilP & $\mathrm{NC}$ & Up & $\ldots$ & $\ldots$ & $\ldots$ & $\ldots$ \\
\hline PD1693 & Pili assembly protein $\mathrm{PilO}$ & pilO & $\mathrm{NC}$ & Up & $\ldots$ & $\ldots$ & Up & $\ldots$ \\
\hline PD1694 & Pili assembly protein PilN & pilN & $\mathrm{NC}$ & Up & $\ldots$ & $\ldots$ & $\ldots$ & $\ldots$ \\
\hline PD1695 & Pili assembly protein PilM & pilM & $\mathrm{NC}$ & $\ldots$ & $\ldots$ & $\ldots$ & Up & $\ldots$ \\
\hline PD1735 & Pili retraction protein PilT & fimT & Up & $\ldots$ & $\ldots$ & $\ldots$ & $\ldots$ & $\ldots$ \\
\hline PD1922 & Type 4 prepilin peptidase & pilD & $\mathrm{NC}$ & $\ldots$ & $\ldots$ & $\ldots$ & $\ldots$ & $\ldots$ \\
\hline PD1923 & Pili assembly protein PilC & pilC & Up & $\ldots$ & $\ldots$ & $\ldots$ & $\ldots$ & $\ldots$ \\
\hline PD1924 & Pili subunit PilA1 & pilA1 & Up & $\ldots$ & $\ldots$ & $\ldots$ & $\ldots$ & $\ldots$ \\
\hline PD1926 & Pili subunit PilA2 & pilA2 & $\mathrm{NC}$ & $\ldots$ & $\ldots$ & Down & $\ldots$ & Down \\
\hline PD1927 & Pili assembly protein PilB & pilB & $\mathrm{NC}$ & Down & Down & $\ldots$ & $\ldots$ & $\ldots$ \\
\hline PD1928 & Two-component response regulator PilR & pilR & $\mathrm{NC}$ & $\ldots$ & Down & $\ldots$ & $\ldots$ & $\ldots$ \\
\hline PD1929 & Sensor protein PilS (EC 2.7.3.-) & pils & $\mathrm{NC}$ & $\ldots$ & $\ldots$ & $\ldots$ & $\ldots$ & $\ldots$ \\
\hline Reference & $\ldots$ & $\ldots$ & $\ldots$ & 59 & 59 & 15 & 21 & 48 \\
\hline
\end{tabular}

${ }^{a}$ WT: wild type; HIC: high iron concentration ( $100 \mu \mathrm{M}$ ferric pyrophosphate); LIC: low iron concentration (treated with the iron chelator $200 \mu \mathrm{M} 2,2^{\prime}$-dipyridyl); NC: no change.

The cell-to-cell signaling system of $X$. fastidiosa appears to regulate a variety of traits that would tend to prevent excessive growth in the nutrient-poor xylem as well as to enhance its tolerance of the stresses associated with high cell densities. Cells of $X$. fastidiosa within densely colonized xylem vessels are apparently mostly dead (8). Thus, although $X$. fastidiosa presumably multiplies rapidly while spreading from one relatively poorly colonized vessel to another (41), its continued growth as vessels become more heavily colonized is probably self defeating. It is noteworthy that a number of key housekeeping genes, including $r p o D$ as well as many genes involved in translation, including $r p s C$, $r p s D, r p s L, r p s O, r p s S, r p l E, r p l P$, and PD0125, were suppressed by RpfF function. A similar observation was made in Xanthomonas citri (27). The suppression of such genes at high cell densities where DSF would accumulate would tend to reduce the growth rate of the cells, thereby avoiding cellular suicide that would result from excessive growth. It is also interesting to note that genes such as PD1403 encoding putative efflux pumps for toxic compounds are upregulated by RpfF. It might be expected that defensive compounds made in response to $X$. fastidiosa infection, or perhaps which might accumulate incidentally as plant tissues were damaged during the process of colonization, would accumulate in concert with the population size of the pathogen. It would be sensible for $X$. fastidiosa to induce traits to deal with such compounds. Such compounds are apparently present in plants because a tolC mutant which would be expected to be blocked in the export of such compounds lost viability soon after inoculation into grape (45). The upregulation of a variety of fimbrial and afimbrial adhesins by RpfF probably plays several important roles. Such genes contribute to biofilm formation. The environment of cells within biofilms has been shown to lead to changes in gene expression that enhance the ability of bacteria to tolerate stress environments (47). It also results in attenuated pathogenicity compared with an rpfF mutant (41). Thus, by enabling biofilm formation, DSF signaling might both directly and indirectly lead to increased stress tolerance of cells in those xylem vessels in which abundant biofilm forms. As shown previously, the increased adhesiveness of cells of $X$. fastidiosa in which DSF signaling is operative, probably mostly due to elevated expression of adhesins such as HxfA and HxfB, is essential for its transmission by sharpshooters $(1,37,41)$. Hypervirulence that is apparently avoided by RpfF signaling is probably not a desirable trait for $X$. fastidiosa because it would reduce the attractiveness of the infected plant for sharpshooter feeding. Thus, $X$. fastidiosa has evolved the RpfF-dependent cell-to-cell signaling system to live in two worlds: plants and insects.

\section{LITERATURE CITED}

1. Almeida, R. P. P., Killiny, N., Newman, K. L., Chatterjee, S., Ionescu, M., and Lindow, S. E. 2012. Contribution of $r p f B$ to cell-to-cell signal synthesis, virulence, and vector transmission of Xylella fastidiosa Mol. 
Plant-Microbe Interact. 25:453-462.

2. Almeida, R. P. P, and Purcell, A. H. 2006. Patterns of Xylella fastidiosa colonization on the precibarium of sharpshooter vectors relative to transmission to plants. Ann. Entomol. Soc. Am. 99:884-890.

3. Araújo, W. L., Marcon, J., Maccheroni, W., van Elsas, J. D., van Vuurde, J. W. L., and Azevedo, J. L. 2002. Diversity of endophytic bacterial populations and their interaction with Xylella fastidiosa in citrus plants. Appl. Environ. Microbiol. 68:4906-4914.

4. Bahar, O., Goffer, T., and Burdman, S. 2009. Type IV pili are required for virulence, twitching motility, and biofilm formation of Acidovorax avenae subsp. citrulli. Mol. Plant-Microbe Interact. 22:909-920.

5. Barber, C. E., Tang, J. L., Feng, J. X., Pan, M. Q., Wilson, T. J. G., Slater, H., Dow, J. M., Williams, P., and Daniels, M. J. 1997. A novel regulatory system required for pathogenicity of Xanthomonas campestris is mediated by a small diffusible signal molecule. Mol. Microbiol. 24:555-566.

6. Bassler, B. L. 2002. Small talk: cell-to-cell communication in bacteria. Cell 109:421-424.

7. Bell, C. R., Dickie, G. A., Harvey, W. L. G., and Chan, J. W. Y. F. 1995. Endophytic bacteria in grapevine. Can. J. Microbiol. 41:46-53.

8. Chatterjee, S., Almeida, R. P. P., and Lindow, S. E. 2008. Living in two worlds: the plant and insect lifestyles of Xylella fastidiosa. Annu. Rev. Phytopathol. 46:243-271.

9. Chatterjee, S., and Sonti, R. V. 2002. rpfF mutants of Xanthomonas oryzae pv. oryzae are deficient for virulence and growth under low iron conditions. Mol. Plant-Microbe Interact. 15:463-471.

10. Chatterjee, S., Wistrom, C., and Lindow, S. E. 2008. A cell-cell signaling sensor is required for virulence and insect transmission of Xylella fastidiosa. Proc. Natl. Acad. Sci. USA 105:2670-2675.

11. Ciraulo, M. B., Santos, D. S., Rodrigues, A. C., de Oliveira, M. V., Rodrigues, T., de Oliveira, R. C., and Nunes, L. R. 2010. Transcriptome analysis of the phytobacterium Xylella fastidiosa growing under xylembased chemical conditions. J. Biomed. Biotechnol. Article 781365. Online publication. doi:10.1155/2010/781365

12. Cooksey, D. A., and Borneman, J. 2005. Culture-independent analysis of endophytic microbial communities in grapevine in relation to Pierce's disease. Pages 155-157 in: Proc. Pierce's Dis. Res. Symp. California Department of Food and Agriculture, San Diego. www.piercesdisease.org/ papers $/ 256$

13. Darzins, A., and Russel, M. A. 1997. Molecular genetic analysis of type-4 pilus biogenesis and twitching motility using Pseudomonas aeruginosa as a model system: a review. Gene 192:109-115.

14. da Silva Neto, J. F., Koide, T., Gomes, S. L., and Marques, M. V. 2007. The single extracytoplasmic-function $\sigma$ factor of Xylella fastidiosa is involved in the heat shock response and presents an unusual regulatory mechanism. J. Bacteriol. 189:551-560.

15. da Silva Neto, J. F., Koide, T., Gomes, S. L., and Marques, M. V. 2010. Global gene expression under nitrogen starvation in Xylella fastidiosa: contribution of the $\delta^{54}$ regulon. BMC Microbiol. 10:231.

16. Deng, Y., Wu, J., Tao, F., and Zhang, L. H. 2011. Listening to a new language: DSF-based quorum sensing in gram-negative bacteria. Chem. Rev. 111:160-173.

17. de Souza, A. A., Takita, M. A., Coletta-Filho, H. D., Caldana, C., Goldman, G. H., Yanai, G. M., Muto, N. H., de Oliveira, R. C., Nunes, L. R., and Machado, M. A. 2003. Analysis of gene expression in two growth states of Xylella fastidiosa and its relationship with pathogenicity. Mol. Plant-Microbe Interact. 16:867-875.

18. Dow, J. M. 2008. Diversification of the function of cell-to-cell signaling in regulation of virulence within plant pathogenic Xanthomonads. Sci. Signal 1:pe23.

19. Dow, J. M., Feng, J. X., Barber, C. E., Tang, J. L., and Daniels, M. J. 2000. Novel genes involved in the regulation of pathogenicity factor production within the rpf gene cluster of Xanthomonas campestris. Microbiology 146:885-891.

20. Feng, J. X., Song, Z. Z., Duan, C. J., Zhao, S., Wu, Y. Q., Wang, C., Dow, J. M., and Tang, J. L. 2009. The xrvA gene of Xanthomonas oryzae pv. oryzae, encoding an $\mathrm{H}-\mathrm{NS}$-like protein, regulates virulence in rice. Microbiology 155:3033-3044.

21. Fogaça, A. C., Zaini, P. A., Wulff, N. A., da Silva. P. I., Fázio, M. A., Miranda, A., Daffre, S., and da Silva, A. M. 2010. Effects of the antimicrobial peptide gomesin on the global gene expression profile, virulence and biofilm formation of Xylella fastidiosa. FEMS Microbiol. Lett. 306:152-159.

22. Franza, T., Sauvage, C., and Expert, D. 1999. Iron regulation and pathogenicity in Erwinia chrysanthemi 3937: Role of the Fur repressor protein. Mol. Plant-Microbe Interact. 12:119-128.

23. Fry, S. M., and Milholland, R. D. 1990. Response of resistant, tolerant and susceptible grapevine tissues to invasion by the Pierce's bacterium, Xylella fastidiosa. Phytopathology 80:66-69.

24. Ghosh, D., Roy, K., Williamson, K. E., Srinivasiah, S., Wommack, K. E., and Radosevich, M. 2009. Acyl-homoserine lactones can induce virus production in lysogenic bacteria: an alternative paradigm for prophage induction. Appl. Environ. Microbiol. 75:7142-7152.

25. Guilhabert, M. R., and Kirkpatrick, B. C. 2005. Identification of Xylella fastidiosa antivirulence genes: hemagglutinin adhesins contribute to $X$. fastidiosa biofilm maturation and colonization and attenuate virulence. Mol. Plant-Microbe Interact. 18:856-868.

26. Guo, Y., Figueiredo, F., Jones, J., and Wang, N. 2011. HrpG and HrpX play global roles in coordinating different virulence traits of Xanthomonas axonopodis pv. citri. Mol. Plant-Microbe Interact. 24:649-661.

27. Guo, Y., Zhang, Y., Li, J. L., and Wang, N. 2012. DSF-mediated quorum sensing plays a central role in coordinating gene expression of Xanthomonas citri subsp. citri. Mol. Plant-Microbe Interact. 25:165-179.

28. Harvie, D. R., Vilchez, S., Steggles, J. R., and Ellar, D. J. 2005. Bacillus cereus Fur regulates iron metabolism and is required for full virulence. Microbiology 151:569-577.

29. He, Y. W., Wu, J., Cha, J. S., and Zhang, L. H. 2010. Rice bacterial blight pathogen Xanthomonas oryzae pv. oryzae produces multiple DSF-family signals in regulation of virulence factor production. BMC Microbiol. 10:187.

30. He, Y. W., Xu, M., Lin, K., Ng, Y. J., Wen, C. M., Wang, L. H., Liu, Z. D., Zhang, H. B., Dong, Y. H., Dow, J. M., and Zhang, L. H. 2006. Genome scale analysis of diffusible signal factor regulon in Xanthomonas campestris pv. campestris: Identification of novel cell-cell communication-dependent genes and functions. Mol. Microbiol. 59:610-622.

31. He, Y., and Zhang, L. H. 2008. Quorum sensing and virulence regulation in Xanthomonas campestris. FEMS Microbiol. Rev. 32:842-857.

32. Hertle, R. 2005. The family of Serratia type pore forming toxins. Curr. Protein Peptide Sci. 6:313-325.

33. Hill, B. L., and Purcell, A. H. 1995. Multiplication and movement of Xylella fastidiosa within grapevine and four other plants. Phytopathology 85:1368-1372.

34. Hopkins, D. L. 1985. Physiological and pathological characteristics of virulent and avirulent strains of the bacterium that causes Pierce's disease of grapevine. Phytopathology 75:713-717.

35. Hopkins, D. L. 1989. Xylella fastidiosa-xylem-limited bacterial pathogen of plants. Annu. Rev. Phytopathol. 27:271-290.

36. Killiny, N., and Almeida, R. P. 2009. Host structural carbohydrate induces vector transmission of a bacterial plant pathogen. Proc. Natl. Acad. Sci. USA 106:22416-22420.

37. Killiny, N., and Almeida, R. P. 2009. Xylella fastidiosa afimbrial adhesins mediate cell transmission to plants by leafhopper vectors. Appl. Environ. Microbiol. 75:521-528.

38. Li, Y., Hao, G., Galvani, C. D., Meng, Y., De La Fuente, L., Hoch, H. C., and Burr, T. J. 2007. Type I and type IV pili of Xylella fastidiosa affect twitching motility, biofilm formation and cell-cell aggregation. Microbiology 153:719-726.

39. Livak, K. J., and Schmittgen, T. D. 2001. Analysis of relative gene expression data using real-time quantitative PCR and the $2^{-\Delta \Delta C}{ }_{T}$ method. Methods 25:402-408.

40. Meng, Y., Li, Y., Galvani, C. D., Hao, G., Turner, J. N., Burr, T. J., and Hoch, H. C. 2005. Upstream migration of Xylella fastidiosa via pilusdriven twitching motility. J. Bacteriol. 187:5560-5567.

41. Newman, K. L., Almeida, R. P. P., Purcell, A. H., and Lindow, S. E. 2004. Cell-cell signaling controls Xylella fastidiosa interactions with both insects and plants. Proc. Natl. Acad. Sci. USA 101:1737-1742.

42. Park, J. H., Lee, Y. S., Lim, Y. K., Kwon, S. H., Lee, C. U., and Yoon, B. S. 2000. Specific binding of recombinant Listeria monocytogenes p60 protein to Caco-2 cells. FEMS Microbiol. Lett. 186:35-40.

43. Purcell, A. H. 1997. Xylella fastidiosa, a regional problem or global threat? J. Plant Pathol. 79:99-105.

44. Purcell, A. H., and Hopkins, D. L. 1996. Fastidious xylem-limited bacterial plant pathogens. Annu. Rev. Phytopathol. 34:131-151.

45. Reddy, J. D., Reddy, S. L., Hopkins, D. L., and Gabriel, D. W. 2007. TolC is required for pathogenicity of Xylella fastidiosa in Vitis vinifera grapevines. Mol. Plant-Microbe Interact. 20:403-410.

46. Ryan, R. P., McCarthy, Y., Andrade, M., Farah, C. S., Armitage, J. P., and Dow, J. M. 2010. Cell-cell signal-dependent dynamic interactions between HD-GYP and GGDEF domain proteins mediate virulence in Xanthomonas campestris. Proc. Natl. Acad. Sci. USA 107:5989-5994.

47. Schembri, M. A., Givskov, M., and Klemm, P. 2002. An attractive surface: gram-negative bacterial biofilms. Science STKE 132:RE6.

48. Shi, X. Y., Dumenyo, C. K., Hernandez-Martinez, R., Azad, H., and Cooksey, D. A. 2007. Characterization of regulatory pathways in Xylella fastidiosa: Genes and phenotypes controlled by algU. Appl. Environ. Microbiol. 73:6748-6756.

49. Shi, X. Y., Dumenyo, C. K., Hernandez-Martinez, R., Azad, H., and Cooksey, D. A. 2009. Characterization of regulatory pathways in Xylella fastidiosa: genes and phenotypes controlled by gacA. Appl. Environ. Microbiol. 75:2275-2283. 
50. Slater, H., Alvarez-Morales, A., Barber, C. E., Daniels, M. J., and Dow, J. M. 2000. A two-component system involving an HD-GYP domain protein links cell-cell signaling to pathogenicity gene expression in Xanthomonas campestris. Mol. Microbiol. 38:986-1003.

51. Smyth, G. K. 2004. Linear models and empirical Bayes methods for assessing differential expression in microarray experiments. Stat. Appl. Genet. Mol. Biol. 3:Article 3.

52. Stoodley, P., Sauer, K., Davies, D. G., and Costerton, J. W. 2002. Biofilms as complex differentiated communities. Annu. Rev. Microbiol. 56:187209.

53. Subramoni, S., and Sonti, R. V. 2005. Growth deficiency of a Xanthomonas oryzae pv. oryzae fur mutant in rice leaves is rescued by ascorbic acid supplementation. Mol. Plant-Microbe Interact. 18:644-651.

54. Wei, K., Tang, D. J., He, Y. Q., Feng, J. X., Jiang, B. L., Lu, G. T., Chen, B., and Tang, J. L. 2007. hpaR, a putative marR family transcriptional regulator, is positively controlled by $\mathrm{HrpG}$ and $\mathrm{HrpX}$ and involved in the pathogenesis, hypersensitive response, and extracellular protease production of Xanthomonas campestris pathovar campestris. J. Bacteriol. 189:2055-2062.

55. Whitehead, N. A., Barnard, A. M. L., Slater, H., Simpson N. J. L., and Salmond, G. P. C. 2001. Quorum sensing in gram-negative bacteria.
FEMS Microbiol. Rev. 25:365-404.

56. Wolfaardt, G. M., Lawrence, J. R., Headley, J. V., Robarts, R. D., and Caldwell, D. E. 1994. Microbial exopolymers provide a mechanism for bioaccumulation of contaminants. Microbiol. Ecol. 27:279-291.

57. Yan, Q., and Wang, N. 2011. The ColR/ColS two-component system plays multiple roles in the pathogenicity of the citrus canker pathogen Xanthomonas citri subsp. citri. J. Bacteriol. 193:1590-1599.

58. Yang, Y., Dudoit, S., Lin, D., Peng, V., Ngai, J., and Speed, T. 2002. Normalization for cDNA microarray data: a robust composite method addressing single and multiple slide systematic variation. Nucleic Acids Res. 30:e15.1-e15.10.

59. Zaini, P. A., Fogaca, A. C., Lupo, F. G., Nakaya, H. I., Vencio, R. Z., and da Silva, A. M. 2008. The iron stimulon of Xylella fastidiosa includes genes for type IV pilus and colicin V-like bacteriocins. J Bacteriol. 190:2368-2378.

60. Zhang, S., He, Y., Xu, L., Chen, B., Jiang, B., Liao, J., Cao, J., Liu, D., Huang, Y., and Liang, X. 2008. A putative colRXC1049-colSXC1050 twocomponent signal transduction system in Xanthomonas campestris positively regulates $h r p C$ and $h r p E$ operons and is involved in virulence, the hypersensitive response and tolerance to various stresses. Res. Microbiol. 159:569-578. 